\title{
A PÁLYAÉRDEKLŐDÉS KAPCSOLATA A PÁLYAVÁLASZTÁSI BIZONYTALANSÁGGAL ÉS A KARRIERDÖNTÉSI ÉN-HATÉKONYSÁGGAL
}

\author{
Szerző: \\ Tudlik Csilla (Drs.) \\ Eszterházy Károly Egyetem
}

Szerző e-mail címe:

csillatudlik@gmail.com

\author{
Lektorok: \\ Mező Ferenc (PhD) \\ Eszterházy Károly Egyetem \\ Szabóné Balogh Ágota (PhD) \\ Gál Ferenc Egyetem \\ ...és további két anonim lektor
}

\begin{abstract}
Absztrakt
A pályaválasztás elvitathatatlan szereplője a pályaérdeklődés, annak vizsgálata mégis hiányt szenved hazánkban. Tanulmányunkban két kérdést vetünk fel: a pályaérdeklődés, karrier én-hatékonyság és pályaválasztási bizonytalanság tekintetében kimutatható-e különbség a nem, kor, településszerkezet és tanulmányi eredményesség tekintetében, illetve hogyan függ össze a pályaérdeklődés a hatékonyság és a bizonytalanság jelenségével. Ezek megválaszolásához pályatanácsadáson részt vevő gimnáziumi tanulók $(n=57)$ kismintás vizsgálatát végeztük el. Megállapítottuk, hogy a pályaérdeklődés esetén mutatható ki a nem, az életkor és a településszerkezet szerint különbség a tanulók között, valamint a pályaérdeklődés intenzitása nem, de egyes területei összefüggnek a pályaválasztási bizonytalansággal (negatívan) és a karrierdöntési én-hatékonysággal (pozitívan).

Kulcsszavak: pályaérdeklődés, karrier én-hatékonyság, pályaválasztási bizonytalanság

Diszciplina: pedagógia, pszichológia

Abstract

RELATIONSHIP BETWEEN CAREER INTEREST AND CAREER CHOICE UNCERTAINTY AND CAREER SELF-EFFICACY

Career interest has an undisputed role in career decision, however, its thorough examination lacks in our country. The study has raised two questions: whether any difference can be detected on interest, career self-efficacy and career indecision by gender, age, living area and academic achievement, furthermore how interest correlates with the phenomenon of career self-efficacy and indecision. To answer an examination was conducted on small sample of secondary school students $(n=57)$ who took part in career counselling. It was stated that (1) there is difference between the students' interest in terms of gender, age and living area; (2) the intensity of interest does not, but (3)
\end{abstract}


distinct part of the interest correlate with career indecision (negatively) and career selfefficacy (positively).

Keywords: career interest, career self-efficacy, career indecision

Disciplines: pedagogy, psychology

Tudlik Csilla (2020): A pályaérdeklődés kapcsolata a pályaválasztási bizonytalansággal és a karrierdöntési én-hatékonysággal. OxIPO - interdiszciplináris tudományos folyóirat, 2020/3, 43-54. doi: 10.35405/OXIPO.2020.3.43

\section{IRODALMI ÁTTEKINTÉS}

Valamennyi pályaválasztási elméletben elvitathatatlan szerepe van a pályaérdeklődésnek, mégis kevés figyelmet kap hazánkban az utóbbi időben. A pályaérdeklődés feltárása nem öncélú tevékenység, sokkal több, mint a jó iskola kiválasztása vagy a kívánatos szakmai képzés megtalálása. Újabb és újabb, akár évtizedeket átölelő kutatások is bizonyítják, hogy az érdeklődés összefügg a munkahelyi beválással, a mentális jólléttel, az elégedettséggel és a sikerérzettel (Allen és Robbins 2008, 2010, Dik és Hansen 2008).

A pályaérdeklődéssel kapcsolatban álló tényezőket többször vetették már vizsgálat alá, ilyen a nem, az életkor, a társadalmi-gazdasági státusz vagy a tanulmányi eredményesség. Ezek közül bizonyítottnak tűnik, hogy a nem egyértelműen befolyásoló tényező, a férfiak általában a tárgyakkal, míg a nók az emberekkel foglalkoznak szívesebben.

Számos kutatás azonban kimutatta (Christensen és Knezek, 2017, Li és Liu, 2015, Ekore, 2014, Ludwickowski és tsai,
2019, Su és tsai, 2009), hogy a műszaki terület nem a férfiak privilégiuma, a nôk ugyanúgy fel tudnak zárkózni tudásban, érdeklődésben, aprólékosabbak a feladatmegoldások során, és motiváltabbak (Henderlong és Lepper, 2007, Ion, Nye és Iliescu, 2019), ha nem őket, hanem az elért teljesítményüket dicsérik.

Az életkor tekintetében az rajzolódott ki (Low és tsai, 2005, Schultz és tsai, 2017), hogy az évek előrehaladtával stabilizálódik az érdeklődés, körülbelül kora felnôttkorra válik egyértelművé, mi fontos az egyén számára a munkákat leíró tevékenységek közül. Többen kimutatták (Diemer és Ali, 2009), hogy a családi környezet, a szülők végzettsége, és a lakóhely hatással van az érdeklődésre, hiszen az a miliő, amelyben az egyén él, amit maga körül lát és tapasztal, illetve amire a szülői indíttatás sarkallja, döntő lehet.

A fent elemzett tényezők egyirányú kapcsolatban állnak a pályaérdeklődéssel, hiszen azok befolyásolják az érdeklődés kialakulását, fordítva azonban ez nem lehetséges (eltekintve attól, hogy bizonyos 
esetben az érdeklődés és az abból kiinduló pályaválasztás nyomán olyan társadalmi-gazdasági lehetőségekre tehet szert az egyén, melyben korábban nem volt része.)

Más tényezők viszont, mint a karrierdöntési én-hatékonyság, a tanulmányi eredményesség vagy a pályaválasztási bizonytalanság kölcsönösségi kapcsolatban áll a pályaérdeklődéssel. Az első két jelenséget kiterjedt kutatás tárta már fel. Azt találták (Holland, 1997, Boyle, 2007 Patrick, Care és Ainley, 2011), hogy akinek kifejezettebb az érdeklődése, annak jobb az iskolai teljesítménye, motiváltabb, célkitűzése biztosabb, de fordítva is érvényes lehet, hiszen a jó tanulmányi eredmény, a hatékonyabb kognitív képességek bizonyos érdeklődési területeket vonzhatnak.

A karrierdöntési én-hatékonyság érdeklődéssel való összefüggésének megértéséhez Lent és munkatársai (1994) alakítottak ki értelmezési keretet. Megállapították, hogy a személyes inputokon, háttértényezőkön és a tanulási tapasztalatokon keresztül az én-hatékonyság hat az érdeklődésre, vagyis az önmagába vetett hit, hogy képesnek tartja magát a célkitűzésre, tervezésre, információgyűjtésre és megvalósításra, olyan érdeklődési területek felé irányítja az egyént, amelyben ezeket a jellemzőket kiélheti.

Kevés figyelmet kapott azonban a pályaválasztási bizonytalanság és a pályaérdeklődés közötti kapcsolat feltárása. Több kutatás arra a következtetésre jutott, hogy a bizonytalanoknak kevésbé van kialakult érdeklődésük, vagyis negatív kapcsolatban állnak, akárcsak az én-hatékonysággal (Guay és munkatársai, 2003, Taylor és Betz, 1983; Betz és tsai, 1996, 1997). A jó tanulók kevésbé bizonytalanok, és az idő előrehaladtával a bizonytalanság csökken. Holland (1997) három okban határozta meg a bizonytalanságot, melyet Osipow (1999) kiegészített eggyel:

1) a személy több ellentétes érdeklődési területtel jellemezhető,

2) nincs kialakult érdeklődése,

3) túl széles az érdeklődése vagy

4) tehetségéből kifolyólag több területre alkalmas lehet.

Releváns kutatások (Creed, Prideaux, és Patton, 2006, Feldman, 2003) azt állítják, a bizonytalanság és az érdeklődés negatív viszonyban fejezhető ki, azaz minél erősebb valaki vonzalma egy szakterület iránt, annál kevésbé kell a bizonytalansággal megküzdenie.

\section{MÓDSZEREK ÉS MINTA}

Magyar tanulói mintán történtek vizsgálatok a pályaválasztási bizonytalanság (Lukács, 2012) és a karrierdöntési énhatékonyság (Török, 2016) tekintetében, jelen tanulmány célja pedig az, hogy a pályaérdeklődést is bevonja a vizsgálatok körébe, különösen az előbbi két jelenséggel kapcsolatban. Felvetéseinket a következőkben fogalmaztuk meg:

1. Különbség van a pályaválasztási bizonytalanság, a karrier én-hatékony- 
ság és a pályaérdeklődés értékeiben nem, település, életkor és tanulmányi eredmény szerint.

2. Összefüggés van a pályaérdeklődés és a nem, település, életkor és tanulmányi eredmény szerint.

3. A pályaválasztási bizonytalanság negatívan hat a pályaérdeklődésre.

4. A karrierdöntési én-hatékonyság szintje pozitívan befolyásolja a pályaérdeklődést.

Vizsgálatunkat kérdőíves módszerrel végeztük, melyet nemre, életkorra, tanulmányi eredményre és a lakhelyre vonatkozó adatokkal egészítettük ki.

A Karriertábla (ODCTE-Tudlik, 2015) nevű eszköz a középiskolás korosztály pályaérdeklődésének felmérését teszi lehetővé önértékelés segítségével. A kérdőív tizenhat - elsősorban a felsőoktatási tudományterületeket lefedő - érdeklődést azonosít a kedvelt tevékenységek, jellemző tulajdonságok és kiemelt témák kombinációja szerint:

1. Agrár, természeti erőforrások, élelmi szer,

2. Építészet, épített környezet,

3. Mûvészet, kommunikáció, technológia,

4. Üzleti adminisztráció,

5. Oktatás-képzés,

6. Pénzügyek,

7. Kormányzati adminisztráció,

8. Egészségügy,

9. Turizmus-vendéglátás,

10. Humán szolgáltatás,

11. Információtechnológia,
12. Jog, közbiztonság,

13. Gyártás,

14. Kereskedelem-marketing,

15. Matematika, mérnöki, tudományos tevékenység,

16. Logisztika.

A tanulóknak az egyes területek iránti attitűdjét egy 17 fokozatú skálán kell jelölniük.

A Pályaválasztási Bizonytalanság Skála (Chartrand et al., 1990) négy faktor (szorongás, információszükséglet, önismeret, általános bizonytalanság) segítségével tárja fel a diákra vonatkozó döntési nehézség okát. A kérdőív öt fokozatú skálát alkalmaz a válaszok rögzítésére.

A Karrierdöntési én-hatékonyság (Betz, Klein \& Taylor, 1996) kérdőív öt faktora (önbecsülés, célkitűzés, információgyűjtés, megvalósítás és tervezés) azt vizsgálja, mennyire hisz önmagában az egyén, mennyire képes elképzeléseihez erőit mozgósítani és azokat megvalósítani. A kérdőív szintén öt fokozatú skálát alkalmaz a válaszok rögzítésére.

Elővizsgálatunkat olyan gimnáziumi tanulók körében végeztük, akik pályatanácsadáson vettek részt. Leíró statisztikájukat az 1. táblázat tartalmazza.

\section{1. táblázat A minta leiró statisztikája (forrás:}

\begin{tabular}{ccccc}
$a S_{\text {zerะő }}$ & & & & \\
\hline \multirow{2}{*}{ Nem } & $\mathbf{1 0 .}$ & $\mathbf{1 1 .}$ & $\mathbf{1 2 .}$ & $\ddot{O}_{\text {ssz. }}$ \\
& évf. & évf. & évf. & \\
\hline fiú & 23 & 1 & 2 & 26 \\
lány & 24 & 2 & 5 & 31 \\
\hline$\ddot{O}$ ssz. & 47 & 3 & 7 & 57 \\
\hline
\end{tabular}


A mintában túlsúlyban voltak a tizedik évfolyamos tanulók, illetve a megyeszékhelyen élők (53\%), így csak nem tekintetében igazán kiegyensúlyozott a vizsgálatban résztvevők köre. Tanulmányi eredményük átlaga 4,37 (SD 0,663).

\section{EREDMÉNYEK}

A pályaválasztási bizonytalanság és a karrierdöntési én-hatékonyság esetében nem mutatható ki szignifikáns különbség a nem, az életkor, a településszerkezet vagy a tanulmányi eredményesség szerint. Úgy tűnik, ezek a pályaérdeklődéssel egyirányú kapcsolatban álló tényezők nem befolyásolják sem a döntésben való bizonyosságot, sem pedig azt, mennyire bízik az egyén saját magában, képességeiben, hogy meg tudja valósítani elképzeléseit. Megállapítható azonban, hogy míg a fiúk több információt szeretnének a lehetséges szakterületekről, addig a lányok általában bizonytalanabbak, szorongóbbak és több önismeretre van szükségük. Ez utóbbi a nemi szerepek konfliktusából is adódhat, vagyis ha vonzódik is a társadalom által a férfiaknak szánt szakmák iránt, kétségei vannak, hogy neki való-e, illetve amenynyiben elfogadjuk a kutatások eredményeit, miszerint a nők szívesebben választanak az emberekkel kapcsolatos tevékenységek közül, akkor a nagy választék miatt - melyre Feldman (2003) hívta fel a figyelmet - eluralkodik a bizonytalanság.

A 10. évfolyamosok szorongóbbak és rendkívül információéhesek, a tizenegye- dikeseknél önismeretigény a kifejezett, míg a végzősök általában bizonytalanabbak. Az évfolyamok én-hatékonyságára jellemző, hogy a legfiatalabbak jók a tervezésben, a tizenegyedikesek szeretnek célt kitűzni, míg a végzősök önbecsülése magasabb és információkeresésben jók. Látható tehát, hogy a minta követi az évfolyamokról alkotott képet, hiszen a tizedik az első évfolyam, amelyikre döntés hárul, tizenegyedik az átmenet, a tényleg jó döntés volt-e kérdéssel tudnak azonosulni, míg a végzősök komolyabb elhatározásokról tudnak beszámolni, illetve feltehetően jól használják a számukra fejlesztett csatornákat, mint a Felvi.hu, nyílt felsőoktatási napok vagy az Educatio kiállítás.

A községben élők körében nagy a bizonytalanság, míg a kisvárosban élőknél a legkevésbé jellemző. A legalacsonyabb énhatékonyságot a megyeszékhelyi diákok mutatják, míg a városban élők hatékonysága a legmagasabb. Feltételezhetően a bizonytalanság és a hatékonyság szintje a települések szerinti túl kevés vagy túl sok lehetőséghez való hozzáférést jelezheti.

Mintánk tanulmányi átlaga egyik jelenséget sem befolyásolta. A kitűnők a legkevésbé bizonytalanok, míg a négyes átlagúak a leginkább bizonytalanok döntésükben, talán mert ők sem a túl jó, sem pedig a túl rossz kategóriába nem érzik odatartozónak magukat. Érdekes, hogy a karrierdöntési én-hatékonyság a közepes tanulók körében mutat jellegzetességet, a hármas tanulók érzik leginkább az én- 
hatékonyságot, míg a hármas és négyes közöttiek a legkevésbé. A tanulmányi eredmény még a pályaérdeklődést sem befolyásolta. Korábbi eredményekkel már bemutattuk (Tudlik, 2019), hogy a gimnáziumi tanulók körében végzett vizsgálatunk szerint az oktatás-képzés, turizmusvendéglátás, kereskedelem-marketing a legkedveltebb terület minden nemre, évfolyamra és településre nézve. Ez a megállapítás jelen vizsgálatunkra is érvényes, illetve a közepes tanulóknál a legváltozatosabb az érdeklődés mintázata, míg a 3,5 átlaggal bíró diákok figyelmét a legkevésbé keltik fel a szakmai tevékenységek, talán az agrár terület tűnik vonzónak számukra.

Ahol szignifikáns eltérés mutatható ki a fiúk javára, az a pályaérdeklődés köre. Az agrár, az építészet, az üzleti adminisztrá- ció, a pénzügy és az informatika kevésbé fontos a lányok számára. A tizedik évfolyamosok körében nagyon népszerű a pénzügyi-gazdasági terület, ugyanakkor szerepe fokozatosabb csökken (Bonferroni teszt: 10. évf.-12. évf. $p=0,038$, $\mathrm{MD}=2,845, \mathrm{SD}=1,102)$, míg a kereskedelem-marketing igen változékony képet mutat az évfolyamok között.

Az érdeklődési területek közül a humán szolgáltatás (például szociális munka, szociál-pedagógia, pszichológia stb.) esetében mutatható ki szignifikáns eltérés a településszerkezet szerint, mivel a kisvárosban élők kedvelik ezt a tevékenységet, a városi diákok azonban a legkevésbé találják vonzónak a másokkal való foglalatosságot (Bonferroni teszt, kisvárosnagyváros, $\mathrm{p}=0,010, \mathrm{MD}=4,345, \mathrm{SD}=$ 1,305 - lásd még: 2. és 3. táblázat).

2. táblázat: varianciaanalzis szignifikáns ( $p<0,05)$ eredményei (forrás: a Sz̨erzó)

\begin{tabular}{l|l|r|l|r|r|r|r|r}
\hline Változók & SS & df & MS & F & p & ETA & ETA $^{2}$ \\
\hline K1*nem & Between group (Combined) & 28,537 & 1 & 28,537 & 4,226 &, 045 &, 267 &, 071 \\
& Within group & 371,393 & 55 & 6,753 & & & & \\
\hline K6*nem & Between group (Combined) & 53,926 & 1 & 53,926 & 7,366 &, 009 &, 344 &, 118 \\
& Within group & 402,635 & 55 & 7,321 & & & & \\
\hline K11*nem & Between group (Combined) & 88,465 & 1 & 88,465 & 7,109 &, 010 &, 338 &, 114 \\
& Within group & 684,377 & 55 & 12,443 & & & & \\
\hline K6*évfolyam & Between group (Combined) & 57,208 & 2 & 28,604 & 3,868 &, 027 &, 354 &, 125 \\
& Within group & 399,354 & 54 & 7,395 & & & & \\
\hline K14*évfolyam & Between group (Combined) & 86,115 & 2 & 43,058 & 4,337 &, 018 &, 372 &, 138 \\
& Within group & 536,095 & 54 & 9,928 & & & & \\
\hline K10*település & Between group (Combined) & 90,388 & 3 & 30,129 & 3,999 &, 012 &, 430 &, 185 \\
& Within group & 399,331 & 53 & 7,535 & & & & \\
\hline
\end{tabular}

K1: agrár; K6: pénzügyek; K10: humán szolgáltatás; K11: informatika; K14: kereskedelem-marketing 
3. táblázat: Az érdeklödési területek, a pályaválasztási bizonytalanság és a pályadöntési énhatékonyság adatainak leiró statisztikája (n=57). Forrás: a Szerzo"

\begin{tabular}{|c|c|c|c|c|}
\hline Változó & Átlag & Szórás & Minimum & Maximum \\
\hline K1: Agrár... & 6,04 & 2,672 & 1 & 14 \\
\hline K2: Építészet... & 7,23 & 3,012 & 1 & 13 \\
\hline K3: Müvészet... & 6,67 & 3,043 & 2 & 14 \\
\hline K4: Üzleti adminisztráció & 7,05 & 2,552 & 2 & 13 \\
\hline K5: Oktatás-képzés & 8,93 & 2,665 & 3 & 15 \\
\hline K6: Pénzügyek & 6,25 & 2,855 & 0 & 13 \\
\hline K7: Kormányzati admin. & 7,19 & 3,091 & 2 & 15 \\
\hline K8: Egészségügy & 7,05 & 2,906 & 2 & 15 \\
\hline K9: Turizmus-vendéglátás & 8,67 & 2,984 & 3 & 16 \\
\hline K10: Humán szolgáltatás & 7,07 & 2,957 & 1 & 15 \\
\hline K11: Információtechnológia & 6,95 & 3,715 & 0 & 15 \\
\hline K12: Jog, közbiztonság & 7,88 & 3,295 & 2 & 15 \\
\hline K13: Gyártás & 5,58 & 2,891 & 0 & 13 \\
\hline K14: Kereskedelem-marketing & 8,47 & 3,333 & 2 & 14 \\
\hline K15: Matematika, mérnöki... & 5,77 & 3,196 & 1 & 13 \\
\hline K16: Logisztika & 6,74 & 2,553 & 2 & 13 \\
\hline Éh-önbecsülés & 19,12 & 2,639 & 14 & 24 \\
\hline Éh-cél & 17,82 & 2,873 & 8 & 24 \\
\hline Éh-inf. & 20,04 & 2,368 & 15 & 25 \\
\hline Éh-megoldás & 19,21 & 3,069 & 11 & 25 \\
\hline Éh-tervezés & 18,81 & 2,973 & 12 & 24 \\
\hline PV-szorongás & 18,72 & 3,745 & 11 & 26 \\
\hline PV-bizonyt. & 14,40 & 1,801 & 10 & 19 \\
\hline PV-infó & 7,35 & 1,837 & 3 & 10 \\
\hline PV-önismeret & 15,42 & 4,101 & 4 & 20 \\
\hline ÉH-össz. & 95,00 & 10,503 & 73 & 119 \\
\hline PV-össz. & 55,89 & 6,143 & 44 & 71 \\
\hline Érdeklődés össz. & 113,5263 & 31,79011 & 63,00 & 174,00 \\
\hline
\end{tabular}

Holland (1997) elgondolása szerint a pályaérdeklődés elevációja is fontos mérőszám lehet. Az egyes érdeklődési területeken elért pontszámok összességét annak kifejezésére alkalmazta, hogy az egyén általánosságban mennyire intenzív érdeklődéssel rendelkezik. Mintánkban azonban nem volt arra vonatkozó jel, hogy az érdeklődés intenzitása és a pályaválasztási bizonytalanság, valamint a karrierdöntési én-hatékonyság között összefüggés lenne. Nem tudtuk tehát azt az elképzelést bizonyítani, miszerint minél kifejezettebb öszszességében az egyén érdeklődése, vagyis sok területben, tevékenységben és témában talál magának vonzót, annál kevésbé bizonytalan és annál inkább én-hatékony pályadöntésében.

Azt azonban meg tudjuk erősíteni, hogy bizonyos érdeklődési területek összefüg- 
gésben állnak a bizonytalansággal és az én-hatékonysággal, továbbá azok mutatják a korábbi kutatások feltevéseit, vagyis a bizonytalansággal negatív, míg az énhatékonysággal pozitív a kapcsolat.

Az 1. ábrán látható, hogy egyes területeket (építészet, művészet, oktatás, kor- mányzat, humán szolgáltatás, informatika, jog, természettudományos-kutatói) nem érintett meg a bizonytalanság és az énhatékonyság szintje. Ugyanakkor e három jelenség kapcsolata egyértelműen kimutatható.

1. ábra. Az érdeklödés, a bizonytalanság és az én-hatékonyság összefüggései (n=57). Forrás: a Sžrzón

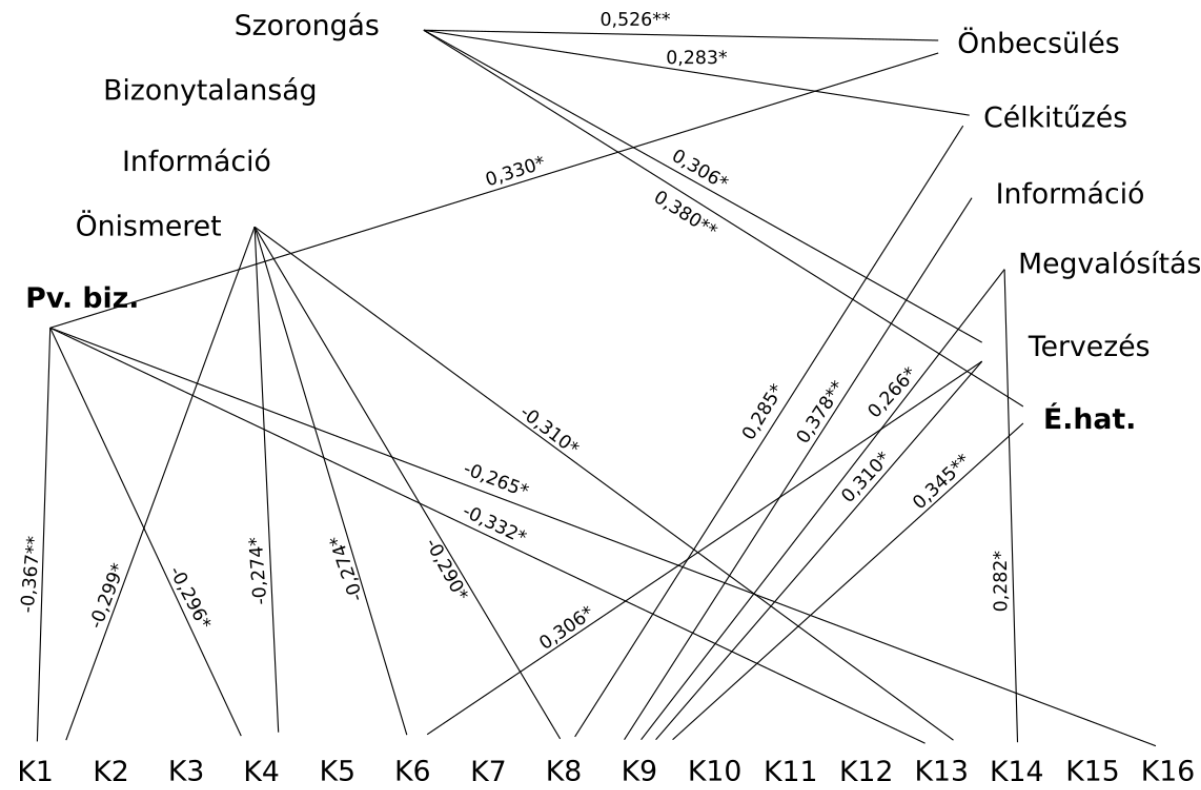

\section{Rövidítések:}

K1: agrár, K2: építészet, K3: müvészet, K4: üzleti adminisztráció, K5: oktatás, K6: pénzügy, K7: kormányzati adminisztráció, K8: egészségügy, K9: turizmus, K10: humán szolgáltatás, K11: IT, K12: jog, K13: gyártás, K14: kereskedelem-marketing, K15: matematika, mérnöki, tudományos, K16: logisztika, Pv.biz.: pályaválasztási bizonytalanság, É.hat.: én-hatékonyság 
Az érdeklődési területeknél úgy tünik, a pályaválasztási bizonytalanság és annak önismereti faktora a valódi befolyásoló tényező. Az agrár, az üzleti adminisztráció, a pénzügy, az egészségügy és a gyártást választók magas önismeretről tesznek tanúbizonyságot, vagy megfordítva, minél kevésbé ismeri önmagát, annál kevésbé választ ezen területek közül. Az összesített pályaválasztási bizonytalanság értéke hasonlóan negatív kapcsolatban áll az agrár, az üzleti adminisztráció, a gyártás és a logisztika területével. Úgy fogalmazhatnánk meg, hogy vizsgálatunk eredménye megegyezik Feldman (2003) gondolatával, miszerint a gyakorlatiasabb foglalkozások, ahol könnyen értelmezhetőek a tevékenységek, kevésbé teszik bizonytalanná a fiatalokat, míg az elméleti feladatokba nehéz beleképzelni önmagukat, ezért ott fokozódik a bizonytalanság.

Lent és munkatársai (1994) szerint az én-hatékonyság hat az érdeklődésre, s tulajdonképpen ez is igazolást nyert vizsgálatunkban. Azok a tanulók, akik hatékonyabbnak érzik magukat, illetve az énhatékonyság összetevőit könnyen alkalmazzák, leginkább az egészségügy, a vendéglátás-turizmus, a kereskedelem-marketing és a pénzügyek területéről választanak maguknak. Vagyis elsősorban olyan szakmákban gondolkodnak, ahol az emberi kapcsolatoknak, a meggyőzésnek, a segítségnyújtásnak, az irányításnak, a szervezésnek és tervezésnek egyaránt szerepe van.
A pályaválasztási bizonytalanság és a karrierdöntési én-hatékonyság jelensége két ponton találkozik. Egyrészt az látszik, hogy összességében a bizonytalanság az Önbecsüléssel van összefüggésben, másrészt az én-hatékonyság a szorongáshoz kapcsolódik. Az azonban kérdéses, hogyan értelmezhető, hogy a gyakorlatias foglalkozások közül választva minél kevésbé bizonytalan az egyén, pozitív önértékelése annál kevésbé kifejezett, hiszen ez ellentmond több eddigi vizsgálatnak (Taylor és Betz, 1983; Betz és mtsai, 1996, Germeijs és Boeck, 2003, Török, 2016). Továbbá az emberekkel kapcsolatos érdeklődési területek inkább a karrierdöntési én-hatékonysággal állnak kapcsolatban, és mintánk alanyai jobban szoronganak. Feldman (2003) arra hívta fel a figyelmet, hogy a humán (és a müvészi) területek nagy változatossága és kevés konkrétuma növelheti a bizonytalanságot.

\section{GYAKORLATI MEGKÖZELÍTÉS}

Tanulmányunkban egy olyan területtel kívántunk foglalkozni, nevezetesen a pályaérdeklődéssel, amely az utóbbi évtizedekben hiányzott a kutatási palettáról. Jelentőségét nehéz lenne vitatni, hiszen valamennyi pályaválasztási elmélet és tanácsadási forma központi szerepet szán neki. Célunk volt, hogy megállapítsuk, a pályaérdeklődés a nemmel, az életkorral, a településszerkezettel vagy a tanulmányi eredményességgel mutat-e összefüggést. Továbbá célunk volt két olyan jelenséggel 
- a karrierdöntési én-hatékonysággal és pályaválasztási bizonytalansággal - összekapcsolni a pályaérdeklődést, amelyek különösen az utóbbi - bőven szolgáltatnak még vizsgálati lehetőséget.

Megállapítottuk, hogy a pályaérdeklődést mintánkban befolyásolja a nem, az életkor és a településszerkezet, ugyanakkor nincs kapcsolatban a tanulmányi eredményességgel.

A pályaérdeklődés intenzitása, vagyis hogy az egyén összességében milyen kíváncsisággal, nyitottsággal fordul a lehetséges tevékenységek felé, sem a személyes jellemzőkkel, sem a lakhellyel, sem pedig a bizonytalanság vagy én-hatékonyság jelenségével nincs összefüggésben mintánkban.

Láthatóvá vált, hogy a triád tagjai egyrészt megfelelnek az előzetesen várt eredménynek, azaz az érdeklődés a pályaválasztási bizonytalansággal negatív, míg a karrierdöntési én-hatékonysággal pozitív viszonyban áll. Másrészt azonban arra is fény derült, hogy a gyakorlatorientált érdeklődési területet választókra nem jellemző a bizonytalanság, ám önbecsülésük ezzel ellentétes irányú, míg az emberekkel kapcsolatos tevékenységeket űzők biztos én-hatékonyságot élnek át, ugyanakkor ez szorongással is eltölti őket.

A középiskolai munkára vonatkozóan úgy fogalmazhatnánk, hogy az önismeret segítése elsődleges fontosságú, az egyéni érdeklődési területek szélesítése a nem figyelembevételével elengedhetetlen, továbbá külső segítséggel a felmerülő szo- rongás kezelése hozzájárulhat az alapos pályadöntés meghozatalához.

\section{IRODALOM}

Allen, J. \& Robbins, S. (2008). Prediction of college major persistence based on vocational interests and first-year academic performance. Research in Higher Education, 49, 62-79. doi: 10.1007/s11162-007-9064-5

Allen, J. \& Robbins, S. (2010). Effects of interest-major congruence, motivation, and academic performance on timely degree attainment. Journal of Counseling Psychology, 57, 23-35. doi: $\underline{10.1037 / \mathrm{a} 0017267}$

Betz, N. E., Klein, K. L., \& Taylor, K. M. (1996). Evaluation of a short form of the Career Decision-Making SelfEfficacy Scale. Journal of Career Assessment, 4, 47-57.

Betz, N. E. \& Voyten, K. K. (1997). Efficacy and outcome expectations influence career exploration and decidedness. Career Development Quarterly, 46, 179-189.

Byole, E. J. (2007). Vocational Interest and other non-cognitive factors as predictors of academic performance in high school. MA disszertáció, University of Johannesburg

Chartrand, J. M. et al. (1990). Development and validiation of the Career Factors Inventory. Journal of Counseling Psychology, Vol. 37., No. 4., 491-501. 
Christensen, R. \& Knezek, G. (2017). Relationship of middle school student STEM interest to career intent. Journal of Education in Science, Environment and Health, 3(1), 1- 13.

Creed, P., Patton, W. \& Prideaux, L-A. (2006) Causal Relationship Between Career Indecision and Career Decision-Making Self-Efficacy: A Longitudinal Cross-Lagged Analysis. Journal of Career Development 33(1):pp. 47-65.

Diemer, A. M. \& Ali, S. R. (2009). Integrating Social Class Into Vocational Psyhology. Journal of Career Assessment 17(3):247-265, doi: $\underline{10.1177 / 1069072708330462}$

Dik, B. J. \& Hansen, J.-I. C. (2008). Following passionate interests to wellbeing. Journal of Career Assessment, 16 (1), 86-100. doi: $\underline{10.1177 /}$ 1069072707305773

Ekore, J. O. (2014). Sex Role Expectations as Predictors of Career Interests among Senior Secondary School students in Ibadan metropolis. Gender \& Behaviour, 12(3), 6211-6222.

Feldman, D. C. (2003). The antecedents and consequences of early career indecision among young adults. $\mathrm{Hu}$ man Resource Management Review, 13, 499-531.

Germeijs, V. \& Boeck, P. D. (2003). Career indecision: Three factors from decision theory. Journal of Vocational Behavior, 62, 11-25.
Guay, F., Senécal, C., Gauthier, L. \& Fernet, C. (2003). Predicting career indecision: A self- determination theory perspective. Journal of Counseling Psychology. 50(2) 165- 177. old.

Henderlong C. J. \& Lepper, M. R. (2007). The effects of person versus performance praise on children's motivation: Gender and age as moderating factors. Educational Psychology, 27(4), 487-508.

Holland, J. L. (1997). Making vocational choices: A theory of vocational personalities and work environments (3rd ed.). Odessa, FL: Psychological Assessment Resources. doi: dx.doi.org/10.1037/ a0033587

Ion, A., Nye, C. D. \& Iliescu, D. (2019). Age and gender differences in the variability of vocational interests. Journal of Career Assessment, 27(1), 97-113 doi: $10.1177 / 1069072717748646$

Lent, R.W., Brown. S.D. \& Hackett, G. (1994). Toward a unifiying social cognitive theory of career and academic interest, choice, and performance. Journal of Vocational Behavior, 42, 79-122.

Li, Yaoran \& Liu, Ruitao (2015). Students' Career Interests and Understanding about Occupations: A Study Using Whyville Players' Behavioral Data. Issue Brief ACT research and policy

Low, K. S. D., Yoon, M., Roberts, B. W. \& Rounds, J. (2005). The stability of interests from early adolescence to middle adulthood: A quantitative review of longitudinal studies. 
Psychological Bulletin, 131(5), 713-737. $\underline{10.1037 / 0033-2909.131 .5 .713}$

Ludwikowski, W. M. A., Schechinger, H. A. \& Armstrong, P. I. (2019). Are Interest Assessments Propagating Gender Differences in Occupations? Journal of Career Assessment, 1-14, doi: $\underline{10.1177 / 1069072718821600}$

Lukács É. F. (2012). A pályaválasżtás és identitásfejlödés összefüggései. A pályaválasztási bizonytalanság típusai az identitásállapotok tükrében. Doktori disszertáció, Budapest: Eötvös Loránd Tudományegyetem

Oklahoma Department of Career and Technology Education (ODCTE) (2005). Career Cluster Interest Survey

Osipow, S. H. (1999). Assessing career indecision. Journal of $V$ ocational Behavior, 55, 147-154.

Patrick, L., Care, E. \& Ainley, M. (2011). The relationship between vocational interests, self-efficacy, and achievement in the prediction of educational pathways. Journal of Career Assessment, 19(1), 61-74. doi: $\underline{10.1177 / 1069072710382615}$
Schultz, L. H., Connolly, J. J., Garrison, S. M., Leveille, M. M. \& Jackson, J. J. (2017). Vocational interests across 20 years of adulthood: Stability, change, and the role of work xperiences. Journal of Research in Personality, 71, 46-56. doi: 10.1016/i.jirp.2017.08.010

Su, R., Rounds, J. \& Armstrong, P. I. (2009). Men and things, women and people: a meta-analysis of sex differences in interests. Psychol. Bull. 135, 859-884. doi: $10.1037 / a 0017364$

Taylor, K. M. \& Betz, N. E. (1983). Applications of self-efficacy theory to understanding treatment of career indecision. Journal of $V$ ocational Behavior, 22, 63-81.

Török R. (2016). A pályadöntési énhatékonyság sajátosságai és változási mintázatai sajátos nevelési igényü és tipikus fejlödésü középiskolások körében. Doktori diszszertáció, Budapest: Eötvös Loránd Tudományegyetem

Tudlik Cs. (2019). Karriertábla a pályatanácsadásban (elóadás). XVII. Pedagógiai Értékelési Konferencia. Szegedi Tudományegyetem 